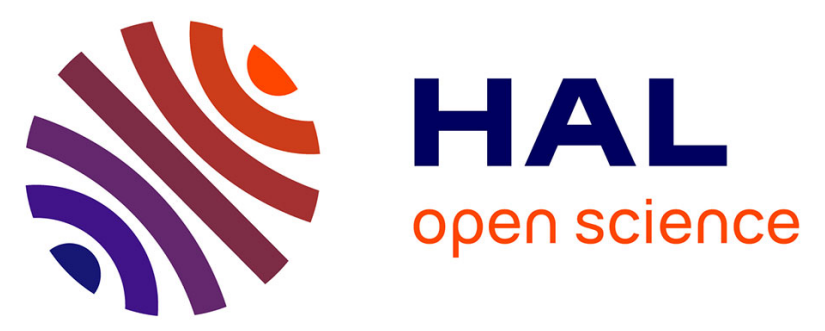

\title{
Fish under influence: a macroecological analysis of relations between fish species richness and environmental gradients among European tidal estuaries
}

D. Nicolas, Jérémy Lobry, Mario Lepage, B. Sautour, Olivier Le Pape, Henrique Cabral, A. Uriarte, Philippe Boët

\section{To cite this version:}

D. Nicolas, Jérémy Lobry, Mario Lepage, B. Sautour, Olivier Le Pape, et al.. Fish under influence: a macroecological analysis of relations between fish species richness and environmental gradients among European tidal estuaries. Estuarine, Coastal and Shelf Science, 2010, 86 (1), p. 137 - p. 147. 10.1016/j.ecss.2009.11.006 . hal-00474505

\section{HAL Id: hal-00474505 \\ https://hal.science/hal-00474505}

Submitted on 20 Apr 2010

HAL is a multi-disciplinary open access archive for the deposit and dissemination of scientific research documents, whether they are published or not. The documents may come from teaching and research institutions in France or abroad, or from public or private research centers.
L'archive ouverte pluridisciplinaire HAL, est destinée au dépôt et à la diffusion de documents scientifiques de niveau recherche, publiés ou non, émanant des établissements d'enseignement et de recherche français ou étrangers, des laboratoires publics ou privés. 
Nicolas, D. etal. Fish under influence: a macroecological analysis of relations between fish species richness and environmental gradients among Eu Estuarine, Coastal and Shelf Science, $n^{\circ} 86$. p. 137-147. 2010.

http://www.sciencedirect.com/science?_ob=PublicationURL\&_tockey=\%23TOC\%236776\%232010\%23999139998\%231577827\%23FLA\%23\&_cdi=

Fish under influence: a macroecological analysis of relations between fish species richness and environmental gradients among European tidal estuaries

Delphine Nicolas $*^{1}$, Jérémy Lobry ${ }^{1,2}$, Mario Lepage ${ }^{1}$, Benoût Sautour ${ }^{3}$, Olivier Le Pape ${ }^{4}$, Henrique Cabral ${ }^{5}$, Ainhize Uriarte ${ }^{6}$, Philippe Bö̈t ${ }^{1}$

${ }^{1}$ Cemagref, UR EPBX, 50 av. de Verdun, F-33612 Cestas, France

${ }^{2}$ GIP Loire Estuaire, Nantes, France

${ }^{3}$ Arcachon Marine station, University of Bordeauxl, France

${ }^{4}$ Université Européenne de Bretagne, UMR 985 Agrocampus Ouest, Inra « Ecologie \& Santé des Ecosystèmes », Ecologie halieutique, Agrocampus Rennes, France

${ }^{5}$ Department of Animal Biology / Institute of Oceanography, University of Lisbon, Portugal

${ }^{6}$ AZTI - Tecnalia / Marine Research Division, Pasaia, Spain

*Corresponding author delphine.nicolas@cemagref.fr

\section{Abstract}

Estuarine fish assemblages are subject to a great environmental variability that largely depends on both upstream fluvial and downstream marine influences. From this ecohydrological view, our study introduces a macroecological approach aiming to identify the main environmental factors that structure fish assemblages among European tidal estuaries. The present paper focuses on the influence of large scale environmental gradients on estuarine fish species richness. The environment of 135 North-eastern Atlantic estuaries from Portugal to Scotland was characterized by various descriptors especially related to hydromorphology. Major environmental trends among estuaries were underlined using multivariate techniques and cluster analyses applied to abiotic data. In particular, an integrative system size covariate was derived from a principal component analysis. Factors explaining patterns of species richness at different scales from local habitat to regional features were highlighted. Based on generalised linear models, the estuarine system size, and more particularly the entrance width, and also the continental shelf width were identified as the best explanatory variables of estuarine fish species richness at a large scale. Our approach provides a standardized method to estimate the relationship between fish assemblages and environmental factors. This constitutes a first step in assessing estuarine ecological status and studying the effects of additional factors such as anthropogenic disturbances. 
Nicolas, D. etal. Fish under influence: a macroecological analysis of relations between fish species richness and environmental gradients among Eu Estuarine, Coastal and Shelf Science, $n^{\circ} 86$. p. 137-147. 2010.

http://www.sciencedirect.com/science?_ob=PublicationURL\&_tockey=\%23TOC\%236776\%232010\%23999139998\%231577827\%23FLA\%23\&_cdi=

Keywords: fish assemblages, tidal estuaries, species richness, large scale, hydromorphology.

\section{Introduction}

Estuaries are transition areas between freshwater and marine habitats that provide many crucial goods and services for human societies (Costanza et al., 1997). Because of high salinity variations, low depths, muddy grounds, high turbidity, various and rich habitats and high food availability, estuaries are also essential for many fish species (Blaber and Blaber, 1980; Elliott and Dewailly, 1995; Beck et al., 2001; Peterson, 2003). These attractive ecosystems are strongly affected by numerous anthropogenic activities (e.g. agriculture, dredging, fishing, harbor activities, industrial pumping, waste water loading), but the degree of human-induced alterations on their ecological functions remains largely unknown (Edgar et al., 2000). Submitted to a highly variable environment, estuarine fish communities vary greatly at different spatial and temporal scales (Maes et al., 2004). Moreover, because estuarine biological communities are well-adapted to cope with high stress, it is difficult to quantify the effects of anthropogenic stress; this is called the estuarine quality paradox (Elliott and Quintino, 2007). It is thus particularly important to characterize key natural ecological patterns before analysing the effects of anthropogenic impacts.

Key natural ecological processes affect estuarine fish communities at different spatial scales. At the local scale, this includes small-scale biotic processes, such as foraging, competition and predation avoidance. Larger-scale but still intra-estuarine ecological patterns result from responses to dominant environmental gradients such as salinity, temperature or turbidity (Blaber and Blaber, 1980; Thiel et al., 1995; Akin et al., 2005). At the global scale of an estuary, ecological features are primarily shaped by three processes: tide, wave and fluvial energies (Dalrymple et al., 1992). Due to a high efficiency in trapping sediment, estuaries tend to accumulate particles (Harris and Heap, 2003). Thus, for example, estuary resilience to 
Nicolas, D. etal. Fish under influence: a macroecological analysis of relations between fish species richness and environmental gradients among Eu Estuarine, Coastal and Shelf Science, $n^{\circ} 86$. p. 137-147. 2010.

http://www.sciencedirect.com/science?_ob=PublicationURL\&_tockey=\%23TOC\%236776\%232010\%23999139998\%231577827\%23FLA\%23\&_cdi= pollution is greatly determined by hydrodynamic forces (e.g. residence time) that influence

rates of sediment flushing (Engle et al., 2007). Estuarine hydrodynamics are under larger scale control, mainly estuary geomorphology, climate (e.g. temperature, rainfall, wind regime) and catchment properties (e.g. substrate, cover, surface, source elevation, dams) (Poff et al., 1996; Peterson, 2003). At this large scale, estuarine fish communities are related to environmental conditions (river flow and temperature) but also to biogeographic species distribution. Main features of estuaries thus strongly influence fish habitats and communities at different scales (Roy et al., 2001; Saintilan, 2004; Harrison and Whitfield, 2006). Consequently, taking into account the large-scale driving factors (Keddy, 1992), macroscopic studies of the relationships between environment and fish assemblage structure may help, first, to understand the functioning of estuarine ecosystems, and then, to assess their ecological status so that appropriate management decisions can be taken (Brown, 1995; Peterson, 2003; Engle et al., 2007).

Identifying and quantifying the links between environmental variables and biota can be carried out through the statistical analyses of long time series data (e.g. Power et al., 2000; Daufresne et al., 2003) or from spatial comparisons of a number of different sites (e.g. Ley, 2005; Harrison and Whitfield, 2006). Previous very large scale American, South African and Australian studies have found estuary mouth configuration (Monaco et al., 1992; Edgar et al., 2000; Ley, 2005; Harrison and Whitfield, 2006), estuarine water area (Monaco et al., 1992; Pease, 1999; Harrison and Whitfield, 2006), latitude (Edgar et al., 1999; Pease, 1999; Harrison and Whitfield, 2006) and catchment area hydrology (Ley, 2005) to be the main abiotic determinants of species richness. Such a large scale investigation has never been carried out on European tidal estuaries fish assemblages. Elliott and Dewailly (1995) compared fish assemblage structure among 17 well-studied European estuaries and underlined a positive influence of estuary area size on fish species number. However, this study was based on heterogeneous fish data, collected by different sampling methods during irregular 
Nicolas, D. etal. Fish under influence: a macroecological analysis of relations between fish species richness and environmental gradients among Eu Estuarine, Coastal and Shelf Science, $n^{\circ} 86$. p. 137-147. 2010.

http://www.sciencedirect.com/science?_ob=PublicationURL\&_tockey=\%23TOC\%236776\%232010\%23999139998\%231577827\%23FLA\%23\&_cdi= survey periods, thus preventing a quantitative comparison (Elliott and Dewailly, 1995). The

present study considers a significantly higher number of estuarine systems, and more especially, uses fishing data collected within the context of the European Water Framework Directive (WFD, European Council Directive, 2000). These WFD fishing surveys, designed to develop fish indicator species to assess the ecological status of transitional waters, and estuaries in particular (Coates et al., 2007), made it possible to create a relatively homogenous European fish data set. Contrary to the previous large scale analyses, especially in South Africa (Harrison and Whitfield, 2006) and Australia (Edgar et al., 1999), where a wide diversity of transitional systems were used (e.g. coastal lagoon, river estuary, permanently or seasonally open estuary, delta), we here focus only on tidal estuaries.

We introduce a macroecological approach that aims, first, at identifying the main features among European tidal estuaries, and secondly, at determining which of these environmental factors influence patterns of fish species richness. The environment of tidal estuaries was described from an ecohydrological view (Wolanski, 2007) by taking into account both upstream and downstream descriptors that may be involved in shaping fish assemblages.

\section{Materials \& Methods}

Two different data matrices were computed in a metabase named EurEFish 1.0 (European Estuaries \& Fish). The first one contained abiotic data collected for 135 European tidal estuaries along a latitudinal gradient from Portugal (Guadiana estuary, $37^{\circ} 10^{\prime} \mathrm{N}, 7^{\circ} 23^{\prime} \mathrm{W}$ ) to Scotland (Donorch estuary, 57 $51^{\prime} \mathrm{N}, 4^{\circ} 00^{\prime} \mathrm{W}$ ) (Fig. 1). The second compiled fish data collected within the WFD monitoring programmes for 81 of the estuaries described.

\subsection{Construction of the abiotic data matrix}

European tidal estuaries were characterised from their main environmental features (Table 1, see appendix A1 for details on the variables). All these estuaries are river valleys drowned by 
Nicolas, D. etal. Fish under influence: a macroecological analysis of relations between fish species richness and environmental gradients among Eu Estuarine, Coastal and Shelf Science, $n^{\circ} 86$. p. 137-147. 2010.

http://www.sciencedirect.com/science?_ob=PublicationURL\&_tockey=\%23TOC\%236776\%232010\%23999139998\%231577827\%23FLA\%23\&_cdi= post-glacial sea level rises 10,000-15,000 years before present (Elliott and McLusky, 2002).

To describe fish estuarine environment from an ecohydrological view, estuary characterization was completed with some descriptors of (upstream) watershed properties and (downstream) marine influence:

\subsubsection{Descriptors of climate and geographic position}

Latitude was included in the database as a proxy for temperature. The selected estuaries belong to the Boreal/Atlantic region (Elliott and Hemingway, 2002). Their watershed is subject to a temperate climate, except the south Portuguese estuaries that support a Mediterranean climate (Olson et al., 2001).

\subsubsection{Descriptors of watershed properties and coastal characteristics}

From the European watershed polygons obtained from River and Catchment database (Catchment Characterisation and Modelling - CCM - version 2.1., Vogt et al., 2007) it was possible to calculate some catchment areas not found in literature using ArcGis software. Source elevation, collected from literature and relief maps, was used as descriptor of the head of the watershed and information of the susceptible water pool (e.g. glacier, snow) or rainfall conditions (through orographic effect) especially for high elevations (i.e. mountain conditions) (Ley, 2005).

Estuaries provide nursery grounds for many marine species that spawn on the continental shelf (Beck et al., 2001; Able, 2005). Continental shelf width and littoral substrate may thus influence the number of marine species able to enter estuaries, and consequently estuarine fish species richness. The minimal distance to the $150 \mathrm{~m}$ depth limit (Fig.1) of the continental shelf was measured with Arcgis software, while the main features of littoral substrate were collected from marine coastal sediment charts.

\subsubsection{Descriptors of estuary geomorphology and hydrological dynamics}

Estuarine morphology was described by estuarine surface area, which is known to enhance habitat diversity (Monaco et al., 1992), and by width and depth at river mouth, which reflect 
Nicolas, D. etal. Fish under influence: a macroecological analysis of relations between fish species richness and environmental gradients among Eu Estuarine, Coastal and Shelf Science, $n^{\circ} 86$. p. 137-147. 2010.

http://www.sciencedirect.com/science?_ob=PublicationURL\&_tockey=\%23TOC\%236776\%232010\%23999139998\%231577827\%23FLA\%23\&_cdi= access to the estuary for marine and diadromous migrant species. The wave exposure factor

provided an indication of the shelter effect provided by these estuaries (Hyndes et al., 1996; Lowry and Suthers, 2004). Areas of intertidal flats, especially recognized for their nursery function (McLusky, 1989; van der Veer et al., 2001; Gibson et al., 2002), were taken into account as a percentage of the total estuarine area, so as not to be redundant with the estuary area variable. Estuary hydrodynamics were characterised by maximal tidal range and mean annual river discharge. Mean annual river discharges were averaged up to the last ten years of data collected through literature or water agency databases (Table 1).

Contrary to the largest well studied estuarine systems (e.g. Tagus - Portugal, Gironde, Seine France, Scheldt - Belgium/Germany, Thames - England), many of the other estuaries studied were relatively small systems for which very few or even no data exist. Consequently, some factors, especially those relating to hydrodynamics, such as tidal prism, water quality and turbidity or to biotic information such as chlorophyll concentration, were not available. For the same reasons, some descriptors (e.g. percentage of intertidal area, wave exposure) were not known precisely but could be estimated qualitatively and expressed as class factors (Table 1). Not all selected abiotic descriptors could be directly linked to fish species distribution; nonetheless these could be viewed as surrogates of more proximal processes. Although the present descriptors did not allow the identification of the underlying processes causing fish species distribution (Austin, 2002), they have the advantage of being easily accessible and allowed patterns of species richness to be studied at a broad scale.

\subsection{Acquisition and preliminary selection of fish data}

Fish data were collected from Portuguese, Spanish, French, Belgian, German, English, Welsh, Scottish and Irish WFD partners. In the WFD context, a large and relatively homogenous fish data set collected on European estuaries was available. Unfortunately, each country has adopted its own sampling strategy leading to intercalibration problems. In particular, beam trawl was the only fishing gear used in Southern Europe (i.e. France, Spain and Portugal), 
Nicolas, D. etal. Fish under influence: a macroecological analysis of relations between fish species richness and environmental gradients among Eu Estuarine, Coastal and Shelf Science, $n^{\circ} 86$. p. 137-147. 2010.

http://www.sciencedirect.com/science?_ob=PublicationURL\&_tockey=\%23TOC\%236776\%232010\%23999139998\%231577827\%23FLA\%23\&_cdi= whereas Northern European countries used a range of tools: for instance, anchor net in the

Elbe and Weser, fyke nets in the Scheldt, beach seines, otter trawl and beam trawl in the United Kingdom. For this study, only beam trawls and beach seines were selected as (i) they represented a large proportion of samples within the database (71\%), (ii) with these gear types, sampling effort can be standardized by their sampled surface.

Within each selected gear type (beam trawl or beach seine), there were differences in mesh size between surveys (see appendix A2). Sampling times could also differ and, for beam trawl, the towing speed. Hence, sampling design and fishing efficiency varied greatly between and among gear types (Steele et al., 2006). Assuming that abundance was more biased by differences in sampling protocols and fishing gears than presence/absence, only presence data were taken into account. Though most of the data were not geographically referenced, that prevented to examine intra-estuary spatial patterns, each estuary was assumed to be sampled along the totality of its upstream-downstream gradient, as specified in WFD sampling protocols. Only fishing surveys that occurred in spring and autumn between 2004 and 2007 were selected. Species richness was chosen to characterize estuarine fish assemblages (see appendix B for further details).

\subsection{Statistical analyses}

\subsubsection{Estuaries classification based on abiotic descriptors}

Estuaries were classified into groups in relation to similarities in physical characteristics based on eight continuous variables: six were geomorphological variables (catchment area, source elevation, estuarine water area, estuary mouth depth and width and continental shelf width) and two hydrological (tidal range and mean river annual discharge). Underlying patterns were identified using principal component analysis (PCA) and clustering with $\mathrm{R}$ software (R Development Core Team, 2005). Preliminary studies showed that latitude was partially correlated to the continental shelf width (Table 2). Thus it was eliminated from the multivariate and classification analyses to allow the resulting patterns to be based on 
Nicolas, D. etal. Fish under influence: a macroecological analysis of relations between fish species richness and environmental gradients among Eu Estuarine, Coastal and Shelf Science, $n^{\circ} 86$. p. 137-147. 2010.

http://www.sciencedirect.com/science?_ob=PublicationURL\&_tockey=\%23TOC\%236776\%232010\%23999139998\%231577827\%23FLA\%23\&_cdi= hydromorphologic features (Clarke and Ainsworth, 1993; Ley, 2005). The quantitative

variables catchment area, source elevation, estuarine water area, estuary mouth width were $\log$-transformed $\ln (x+1)$ to weaken the influence of the few strongest outliers. A normed PCA was computed in order to synthesize the data describing the environmental conditions of estuaries. Estuary clusters were obtained through a Hierarchical Clustering procedure using Ward agglomerative method (LeBart et al., 1984) based on the matrix of Euclidean distance between pairs of sites calculated from their coordinates in the PCA. Correlation between each pair of quantitative variables was calculated with the Pearson correlation coefficient (Table 2).

\subsubsection{Species richness standardization}

The number of species collected during a survey depends on sampling effort (Krebs, 1999). To limit bias due to sampling design, species richness was standardized with relation to the sampled surface. After examination of the shape of species-accumulation curves, only fishing surveys with a total sampled surface of at least $2,500 \mathrm{~m}^{2}$ (per year and per season) were selected. Species richness was then divided by the log-transformed total sampled surface realized during a survey (Krebs, 1999). Through this transformation, the relationship between species richness and sampled surface became linear (Fig.2). Consequently, species richness refers to $S R / \ln (S)$, where $S R$ corresponds to species richness and $S$ to total sampled surface $\left(\mathrm{m}^{2}\right)$ to standardize SR with regard to sampling effort (see appendix B1 for $\mathrm{SR} / \ln (\mathrm{S})$ values per sampled estuary).

\subsubsection{Identification and quantification of main abiotic factors structuring fish species}

\section{richness}

Generalised linear models (GLM) were constructed to identify those abiotic descriptors

(Table 1) which best explained species richness. The two selected gear types could not give homogenous data due to their different sampling properties: beach seine was used on shallow banks, catching species from the entire water column, while beam trawls were designed to catch both demersal and benthic species, within areas deep enough to allow the passage of the 
Nicolas, D. etal. Fish under influence: a macroecological analysis of relations between fish species richness and environmental gradients among Eu Estuarine, Coastal and Shelf Science, ${ }^{\circ} 86$. p. 137-147. 2010.

http://www.sciencedirect.com/science?_ob=PublicationURL\&_tockey=\%23TOC\%236776\%232010\%23999139998\%231577827\%23FLA\%23\&_cdi= boat. As a consequence, two types of models were produced, the first containing both beach

seine and beam trawl data and the second only beam trawls (Table 3). The latter considered only 45 estuaries, but with relatively homogenous data over the entire latitudinal gradient studied: estuaries from Guadiana (Portugal) to Cromarty (Scotland). Preliminary graphic tests on data distribution showed that a GLM based on a Gaussian law was most suitable for modelling fish species richness index. Within the models, we introduced factors related to sampling procedure, when significant, in order to account for possible bias. These factors corresponded to between-years and between-seasons variability of species richness for a given estuarine system. When these two factors were tested non-significant, species richness data were pooled per estuary (instead of per estuary, per year and per season). In the first type of models, the number of fishing gear types used (i.e. one: beam trawl or beach seine; or two: beam trawl and beach seine) was also tested, assuming that when various fishing techniques are used, species richness is greater. We next tested the preselected and uncorrelated abiotic environmental trends in the models. The GLM models can then be written as follows:

$\mathrm{SR} / \mathrm{ln}(\mathrm{S}) \sim$ Year + Season + Number of gear types $+\mathrm{X}_{1 \ldots}+\mathrm{X}_{\mathrm{i}} \ldots+\mathrm{X}_{\mathrm{n}}$, family=Gaussian(link='identity'), where $X_{i}$ represents the abiotic descriptors of estuaries (continuous covariates or class factors).

To choose environmental descriptor(s) $X i$ to introduce within models, we tested each variable separately. Variables were then ordered from the most significant to the least significant and a forward stepwise procedure was carried out to determine the best explicative descriptor(s). According to analyses of variance (Chi-square test at 5\% level), Akaike Information Criterion (AIC) (Sakamoto et al., 1986), ecological relevance and graphical analysis of the residuals, the best final combination of variables was selected. The statistical significance of each descriptor was tested with both a Chi-square test and a Wald test at 5\% level using type-I and type-III ANOVA respectively on $\mathrm{R}$ software. The nature of the effect of the descriptors (i.e. 
Nicolas, D. etal. Fish under influence: a macroecological analysis of relations between fish species richness and environmental gradients among Eu Estuarine, Coastal and Shelf Science, $n^{\circ} 86$. p. 137-147. 2010.

http://www.sciencedirect.com/science?_ob=PublicationURL\&_tockey=\%23TOC\%236776\%232010\%23999139998\%231577827\%23FLA\%23\&_cdi= positive or negative) on species richness was determined from the sign of the corresponding

coefficient(s). A complete graphical analysis of the residuals was carried out for each GLM in order to check that the underlying hypotheses (homogeneity, independence and normality of the residuals) were confirmed. Moreover, further tests of non-linear relationships (function poly on R software) were conducted to estimate this linear approach as appropriate.

\section{Results}

\subsection{Analysis of abiotic attributes and estuaries classification}

Estuaries were clustered into seven groups based on the coordinates associated with the two first main components of the PCA that explained $62.5 \%$ of the total variance in the abiotic data set (Fig. 3). The first component explained $41.7 \%$ of the total inertia and was highly correlated with four variables related to the size of the estuarine systems: catchment area, mean annual river discharge, estuary area and mouth width (Fig. 3b). The second component (20.8\%) was most correlated with three different variables: tidal range, continental shelf width and source elevation (Fig. 3b). Mouth depth, the last variable, was associated with the third component (12.7\%). Estuary clusters were mainly discriminated by system size, tidal range and continental shelf width (Figs 3a and 4). Clusters A and B contained the largest European estuaries (e.g. Gironde, Elbe, Severn), while F and G brought together the smallest systems that represented most of the estuaries studied. The four descriptors related to system size were significantly well correlated (Table 2) and highly associated with the first PCA main component (Fig. 3b). Thus estuary coordinates associated with this first component were considered as a 'size effect' covariate, tested in GLMs.

\subsection{GLM results}

For each type of model, i.e. two-gear-types and beam trawls only, the best ones are presented (Table 3). These models explained a maximum of $28.3 \%$ and $42.7 \%$ respectively of the total 
Nicolas, D. etal. Fish under influence: a macroecological analysis of relations between fish species richness and environmental gradients among Eu Estuarine, Coastal and Shelf Science, $n^{\circ} 86$. p. 137-147. 2010.

http://www.sciencedirect.com/science?_ob=PublicationURL\&_tockey=\%23TOC\%236776\%232010\%23999139998\%231577827\%23FLA\%23\&_cdi= deviance of corresponding data sets (Table $3 \mathrm{a}$ and 3b, respectively 81 and 45 sampled

estuaries).

\subsubsection{Sampling influence}

Season and year were non-significant in explaining fish species richness variability. Consequently, species richness was pooled per system. The 'number of gear types used' variable, tested only in the first type of model, was highly significant, with a positive slope coefficient (Table 3a).

\subsubsection{System size effect}

In both models, the size effect described by the first PCA main component was a highly significant explanatory variable (Table 3). Size effect was positive, meaning that the largest estuarine systems had the greatest fish species richness. Estuaries in clusters A and B had on average a greater species richness index $(\mathrm{SR} / \ln (\mathrm{S})=1.87 ; \mathrm{SD}=0.9)$ compared to estuaries in clusters $\mathrm{F}$ and $\mathrm{G}$ (1.26; $\mathrm{SD}=0.7)$. Among the four size effect variables, entrance width was the most significant explanatory variable when tested alone in the models. Mouth depth improved the beam trawl model (Table 3) and was negatively linked to species richness.

\subsubsection{Downstream and upstream variables}

Species richness was linked to two large scale descriptors: continental shelf width and source elevation (Table 3). North Sea estuaries were characterised by the greatest minimal distance to the $150 \mathrm{~m}$ deep continental shelf $(212.2 \mathrm{~km} ; \mathrm{SD}=49 \mathrm{~km}$ on average), while the Southern estuaries had the smallest $(7.6 \mathrm{~km} ; \mathrm{SD}=4 \mathrm{~km}$ on average for Portuguese and Spanish systems). Conversely, source elevation was greater for the Southern systems, especially due to the presence of the Pyrenees Mountains (Fig. 1). These two descriptors appeared to reflect a similar structure pattern in species richness distribution. Species richness index was on average greater in the eleven North Sea estuaries $(\mathrm{SR} / \ln (\mathrm{S})=2.25 ; \mathrm{SD}=1.1)$ compared to the nine English Channel ones (1.53; SD=0.7), the five Celtic Sea ones (1.57; SD=0.6), the fifteen Bay of Biscay ones (1.25; $\mathrm{SD}=0.7)$ and the five Portuguese ones (1.59; $\mathrm{SD}=0.6)$. The high 
Nicolas, D. etal. Fish under influence: a macroecological analysis of relations between fish species richness and environmental gradients among Eu Estuarine, Coastal and Shelf Science, $n^{\circ} 86$. p. 137-147. 2010.

http://www.sciencedirect.com/science?_ob=PublicationURL\&_tockey=\%23TOC\%236776\%232010\%23999139998\%231577827\%23FLA\%23\&_cdi=

level of species richness observed in the North Sea estuaries was mainly due to values

obtained for the four English estuaries located in the South-East Bay of England (3.43; $\mathrm{SD}=0.4$ on average for Blackwater-Coln, Crouch, Thames and Swale), and for the Tees and Wear estuaries (respectively 2.37 and 2.12).

Lastly, the tidal range, the percentage of intertidal areas and the wave exposure did not provide any additional information to describe fish species richness.

\section{Discussion}

\subsection{Relevance of the large scale analysis}

Standardizing species richness in relation to sampled surface allowed us to take into account the sampling effort to produce richness estimates (Krebs, 1999) and provided reliable interestuary comparisons. By taking into account both beach seine and beam trawl data, a large proportion of fish data from the European WFD sampling surveys (81 out of 116) was included in the analysis. These considerations about discrepancies linked in particular to sampling gear lead us to recommend standardization in future sampling efforts, so that data can be more readily compared among European estuaries. However, in the present study, a covariate that qualified the number of gear types used during a survey was introduced into GLMs and accounted for the variability due to sampling protocol. The best explicative abiotic variables of species richness identified with these two-gear-type models, system size and continental shelf width (or source elevation), were corroborated by a second type of model based solely on beam trawl. This led us to conclude that including different types of sampling gear in a survey in order to better explore fish species richness was relevant, as long as the associated bias was taken into account in the statistical model.

Beach seine was only used in the Republic of Ireland (IRL) and the United Kingdom (GBR), i.e. Northern Europe, so our sampling effort factor could actually reflect a latitudinal effect. Nonetheless, latitude was tested in the GLMs as an explanatory covariate and found to be 
Nicolas, D. etal. Fish under influence: a macroecological analysis of relations between fish species richness and environmental gradients among Eu Estuarine, Coastal and Shelf Science, $n^{\circ} 86$. p. 137-147. 2010.

http://www.sciencedirect.com/science?_ob=PublicationURL\&_tockey=\%23TOC\%236776\%232010\%23999139998\%231577827\%23FLA\%23\&_cdi= non-significant. Furthermore, a student test, carried out for the IRL and GBR estuaries for

which species richness values were retained into the two data sets (i.e. both gear types and beam trawl only, see appendix B1), showed that species richness was significantly higher when taking into account both gear types rather than only one (p-value $<5 \%)$. As a result, the difference among observed species richness was attributed to a better sampling of estuarine fish assemblage.

The best models explained a maximum of $28.3 \%$ of total deviance for the two-gear-types and $42.7 \%$ for the beam trawl. The beam trawl models explained more deviance than the twogear-type models, as they were based on a more homogeneous and smaller data set. These results were convincing, since only large scale abiotic descriptors that encompassed variability from different sources at smaller scales were considered here.

Though not available for all of the estuaries studied, additional descriptors could improve analysis of the relationship between environmental variability and the fish species richness pattern. For instance, annual or seasonal temperature and rainfall data could represent useful information on the influence of climatic conditions upon a catchment area (Pease, 1999; Ley, 2005; Engle et al., 2007). Biological production (Willig et al., 2003) within an estuary and on the adjacent coast and shelf, and for instance the presence of upwelling fronts known to modulate the production and distribution regimes of marine species (e.g. Mann and Lazier, 1991; Bakun, 1996) could also be useful descriptors. The tidal prism volume and mixing could improve the description of hydrological dynamics within estuaries (Poff, 1997; Engle et al., 2007) even if the tidal range and proportion of intertidal areas did not provide any additional information in the present models. Similarly, the diversity of habitats (e.g. nature of bottom substrates, presence of salt marshes) within an estuary were important missing descriptors (Roy et al., 2001; Saintilan, 2004). In spite of these limitations due to data availability, our results still appeared relevant from a macro-scale point of view and identify significant effects from easily accessible descriptors. Nonetheless, as it was collected during 
Nicolas, D. etal. Fish under influence: a macroecological analysis of relations between fish species richness and environmental gradients among Eu Estuarine, Coastal and Shelf Science, $n^{\circ} 86$. p. 137-147. 2010.

http://www.sciencedirect.com/science?_ob=PublicationURL\&_tockey=\%23TOC\%236776\%232010\%23999139998\%231577827\%23FLA\%23\&_cdi=

only one or two seasons for one or a few years, data did not allow us to truly account for

temporal variability. Consequently, longer time series data should be used to confirm our results on a longer temporal scale and take better account of natural variability. Although estuarine fish assemblages are known to vary through time and especially between seasons (Elliott and Hemingway, 2002), both seasonal and inter-annual variability of fish species richness index were found to be statistically non-significant. This result may also be explained by the large scale of our analysis: at this scale slight changes in species numbers between years or seasons were encompassed by stronger effects such as system size and features.

\subsection{Influence of estuarine features on fish species richness}

\subsubsection{System size effect}

Fish species richness was shown to depend on system size, which clearly implies estuary surface area. Estuarine area has already been highlighted as a significant predictor of taxonomic richness in studies of US (Monaco et al., 1992), Australian (Pease, 1999) and South African estuaries (Harrison and Whitfield, 2006) and underlined as a highly probable structuring effect for European estuarine fish assemblages (Elliott and Dewailly, 1995). This result supports the well-studied assumption of species-area relationship which states that species number increases with area. The underlying explanations of this theory include effect of sampling effort (Connor and McCoy, 1979), here previously standardized, and greater habitat diversity (e.g. Roy et al. , 2001). Within European temperate estuaries, nine habitats are recognized as being of importance for estuarine fish: tidal freshwater, reed beds, saltmarsh, intertidal soft, intertidal hard, subtidal soft and hard substrates, subtidal sea grass beds and biogenic reefs (Elliott and Hemingway, 2002). In tropical estuaries, saltmarsh areas are replaced by mangrove vegetation which is of similar ecological importance for fish (Ley, 2005). Due to semi-diurnal tides, European tidal estuaries tend to display a greater diversity of habitats compared to European estuaries in both the (almost non-tidal) Baltic and 
Nicolas, D. etal. Fish under influence: a macroecological analysis of relations between fish species richness and environmental gradients among Eu Estuarine, Coastal and Shelf Science, ${ }^{\circ} 86$. p. 137-147. 2010.

http://www.sciencedirect.com/science?_ob=PublicationURL\&_tockey=\%23TOC\%236776\%232010\%23999139998\%231577827\%23FLA\%23\&_cdi= Mediterranean regions (Elliott and Hemingway, 2002). The present focus on tidal estuaries

hinders analysis of the effect of the tidal range, which was non-significant in the studied dataset. A large European tidal estuary is more likely to contain more diverse habitats than a smaller one, and moreover offers larger habitat area, thus higher carrying capacity. Furthermore, when they are not barred by dams, large estuaries present a complete salinity gradient from tidal freshwater to euryhaline area. By contrast, small estuaries with a low river input tend to fill with marine water only during high tide, without a real mixing zone of brackish water. This supports the assumption that larger estuaries shelter more diverse habitats and species than small ones.

Among size effect descriptors, mouth width was the best predictor of species richness. Indeed, wider estuary mouths optimize access to the estuary for marine transient and diadromous species (Pease, 1999; Roy et al., 2001). Moreover a larger entrance enhances further penetration of seawater. Yet areas under high marine influence are usually richer in species than both mesohaline and freshwater areas (Thiel et al., 1995). Furthermore, marine species were reported worldwide to contribute highly to the total number of species: more than $50 \%$ in the Tagus and Elbe estuaries (Thiel et al., 2003), 50\% on average in estuaries along the European Atlantic seaboard (Elliott and Dewailly, 1995), approximately 70\% in estuaries in south-western Australia and temperate southern Africa (Potter et al., 1990) and 57\% on average in the present study. The extension of downstream marine influence thus promotes species diversity (Pease, 1999). Ley (2005) found that Australian tidal-dominated systems, with their wide deltaic mouth, had a greater richness of fish families compared to the wavedominated systems that presented a constricted mouth. The strong influence of the connectivity with the sea on species richness was also highlighted by both South African and Tasmanian studies (Edgar et al., 1999; Harrison and Whitfield, 2006), within which temporally closed estuaries exhibited lower numbers of fish species than permanently open systems. In European systems, mouth width and mouth depth were found uncorrelated and 
Nicolas, D. etal. Fish under influence: a macroecological analysis of relations between fish species richness and environmental gradients among Eu Estuarine, Coastal and Shelf Science, $n^{\circ} 86$. p. 137-147. 2010.

http://www.sciencedirect.com/science?_ob=PublicationURL\&_tockey=\%23TOC\%236776\%232010\%23999139998\%231577827\%23FLA\%23\&_cdi= with opposite effects on species number, contrary to what was found by Pease (1999) in

Australia and Monaco et al. (1992) in the US. In contrast to the US and Australian areas, large European estuaries with higher species richness were shallower at the mouth (e.g. Guadiana $3.1 \mathrm{~m}$, Seine $-6 \mathrm{~m}$, Loire $-7.5 \mathrm{~m}$ ) than the smaller, species poorer estuaries with deeper entrances (e.g. Cromarty - 33 m, Nervion - 30m, Trieux - 17 m). Besides, shallow and high salinity estuarine habitats are the most attractive to marine species, especially to juveniles, due to high food concentration and refuge from predation (McLusky, 1989; Gibson, 1994). This can hide the influence of wave exposure, found here to be non-significant for species richness.

\subsubsection{Large scale effects: latitude versus continental shelf width}

Theoretically, species richness decreases with increasing latitude. This concept has been verified in many studies for marine (Poore and Wilson, 1993), estuarine (Pease, 1999; Harrison and Whitfield, 2006) and freshwater fish (Oberdorff et al., 1995). Here, latitude was not statistically significant in explaining estuarine fish species richness. This corroborated the results described by Elliott and Dewailly (1995). This may be due to the temperate Northern Atlantic context (Spalding et al., 2007). Most of the estuaries included in this analysis are situated in the Palearctic area, except for the five Portuguese estuaries which are characterised by a warmer Mediterranean climate (Olson et al., 2001). By taking into account more subarctic and subtropical estuaries such as, respectively, Norwegian or North African systems, latitude may become significant (Attrill et al., 2001). Conversely, due to the relationship with the higher continental shelf width in the Northern part of the European study area, North Sea estuaries were shown to be richer in fish species than South European Atlantic ones.

To our knowledge, this is the first time a correlation between European estuarine fish diversity and the continental shelf width has been pointed out. Though the nature of this link may be indirect and, like source elevation, may rather reflect a structural effect of species richness pattern, the following explanations can be considered: first, a wider continental shelf 
Nicolas, D. etal. Fish under influence: a macroecological analysis of relations between fish species richness and environmental gradients among Eu Estuarine, Coastal and Shelf Science, $n^{\circ} 86$. p. 137-147. 2010.

http://www.sciencedirect.com/science?_ob=PublicationURL\&_tockey=\%23TOC\%236776\%232010\%23999139998\%231577827\%23FLA\%23\&_cdi= may shelter a greater surface and variety of spawning grounds for different fish species that

are likely to enter estuaries as juveniles (Beck et al., 2001; Able, 2005). Moreover, fish species richness decreases with increasing depth (Smith and Brown, 2002; Kendall and Haedrich, 2006), so that a wider continental shelf may promote a greater occurrence of different marine species. This could explain why South-East England estuaries were found to be especially rich in species richness.

Portuguese estuaries were slightly richer than those in the Bay of Biscay. This could be explained by size effect, as four of the five estuaries are amongst the largest in the area studied (cluster A, Fig.3). Nonetheless the smallest of these, Mira estuary (cluster F), was also richer. Portuguese coasts are known to be influenced by seasonal upwelling regimes from spring to autumn (Santos et al., 2005), that produce highly productive areas and attract fish (Pauly and Christensen, 1995). South Portuguese estuaries are influenced by surface currents of subtropical origin (Fiuza et al., 1998) that may bring marine species not present in the Bay of Biscay. In the present data set, two subtropical fish species, Diplodus bellottii (Sparidae, Steindachner, 1882) and Monochirus hispidus (Soleidae, Rafinesque, 1814), a Mediterranean species, Symphodus cinereus (Labridae, Bonnaterre, 1788) and ten other species were caught only in Portuguese estuaries. Climate and hydrodynamic features could explain the species richness in this area. With global change and rising water temperatures, tropical fish species may migrate northwards and changes in species spatial distribution are likely to occur (Perry et al., 2005; Désaunay et al., 2006; Hermant et al., in press) and to change the present patterns.

\section{Conclusions}

This is the first time such a large scale analysis of estuarine fish and abiotic environment relationships has been carried out in Europe. Based on relatively homogeneous fish data, this study corroborates the hypothesis that in European tidal estuaries fish species richness increases with estuary size and mouth width, which increases connectivity to the marine 
Nicolas, D. etal. Fish under influence: a macroecological analysis of relations between fish species richness and environmental gradients among Eu Estuarine, Coastal and Shelf Science, $n^{\circ} 86$. p. 137-147. 2010.

http://www.sciencedirect.com/science?_ob=PublicationURL\&_tockey=\%23TOC\%236776\%232010\%23999139998\%231577827\%23FLA\%23\&_cdi=

environment. Species richness was also found to decrease with mouth depth, underlying the

essential nursery role of shallow estuarine areas. The present study especially highlights the effect of the continental shelf width on structuring estuarine fish species richness. Analyses on a much more local scale, taking into account additional descriptors related to more proximal and stochastic processes (Austin, 2007), will help in understanding constraints and causal processes involved in shaping species richness pattern(s). Applying the present approach to functional and quantitative descriptors of fish assemblages will allow a deeper understanding of fish assemblage structure (Franco et al., 2008). The present approach provides a standardized method to compare estuarine systems and estimate the variability in fish species richness due to environmental features. By taking this standardization into account, studying the effects of additional factors such as anthropogenic disturbances will lead to the selection of relevant fish assemblage indicators that will make it possible to assess the ecological status of estuaries (Courrat et al., 2009).

\section{Acknowledgments}

This project was supported by the French Region 'Aquitaine' and by Cemagref institute. We are very grateful to all our European partners for sharing their WFD fish data and answering any further requests so kindly: Steve Coates, Adam Waugh from Environmental Agency (London, England and Wales data), Jimmy King from Central Fisheries Board of Ireland (Dublin, Republic of Ireland data), Peter Moorehead from Marine Monitoring and Assessment Group/Environment and Heritage Service (Lisburn, Northern Ireland data), Alexis Pearce from Scottish Environment Protection Agency (Edinburgh, Scotland data), Jan Breine from the Flemish Research Institute for Nature and Forest (Groenendaal, Scheldt data)

Angel Borja from AZTI - Tecnalia/Marine Research Division (Pasaia, Spain Basque data), Maria José Costa from Institute of Oceanography (Lisbon, Portugal data), Rachid Amara and Jonathan Selleslagh from University of Opale littoral coast (Wimereux, French Authie and 
Nicolas, D. etal. Fish under influence: a macroecological analysis of relations between fish species richness and environmental gradients among Eu Estuarine, Coastal and Shelf Science, $n^{\circ} 86$. p. 137-147. 2010.

http://www.sciencedirect.com/science?_ob=PublicationURL\&_tockey=\%23TOC\%236776\%232010\%23999139998\%231577827\%23FLA\%23\&_cdi=

Canche estuaries data). A great thank you to Samuel Toucanne and Vincent Hanquiez for SIG

data related to continental shelf width and Jean-Marie Jouanneau for his geomorphological view on estuaries (Department of Geology and Oceanography, University of Bordeaux1, France). Special thanks to Maud Cottet for her considerable help in collecting abiotic data, and to Anaïs Just and Aymeric Guibert for SIG assistance (Cemagref, Bordeaux, France). The authors would also like to thank the reviewers for their fruitful comments.

\section{References}

Able, K.W., 2005. A re-examination of fish estuarine dependance : Evidence for connectivity between estuarine and ocean habitats. Estuarine Coastal and Shelf Science 64, 5-17.

Akin, S., Buhan, E., Winemiller, K.O. and Yilmaz, H., 2005. Fish assemblage structure of Koycegiz Lagoon-Estuary, Turkey: Spatial and temporal distribution patterns in relation to environmental variation. Estuarine, Coastal and Shelf Science 64, 671684.

Attrill, M.J., Stafford, R. and Rowden, A.A., 2001. Latitudinal diversity patterns in estuarine tidal fiats: Indications of a global cline. Ecography 24, 318-324.

Austin, M., 2007. Species distribution models and ecological theory: A critical assessment and some possible new approaches. Ecological Modelling 200, 1-19.

Austin, M.P., 2002. Spatial prediction of species distribution: an interface between ecological theory and statistical modelling. Ecological Modelling 157, 101-118.

Bakun, A., 1996. Patterns in the ocean. Ocean processes and marine population dynamics. NOAA. California Sea Grant College System, La Jolla, CA.

Beck, M.W., Heck, K.L., Able, K.W., Childers, D.L., Eggleston, D.B., Gillanders, B.M., Halpern, B., Hays, C.G., Hoshino, K., Minello, T.J., Orth, R.J., Sheridan, P.F. and Weinstein, M.R., 2001. The identification, conservation, and management of estuarine and marine nurseries for fish and invertebrates. Bioscience 51, 633-641.

Blaber, S.J.M. and Blaber, T.G., 1980. Factors affecting the distribution of juvenile estuarine and inshore fish. Journal of Fish Biology 17, 143-162.

Brown, J.H., 1995. Macroecology. The University of Chicago Press, London., 269 pp. 
Nicolas, D. etal. Fish under influence: a macroecological analysis of relations between fish species richness and environmental gradients among Eu Estuarine, Coastal and Shelf Science, $n^{\circ} 86$. p. 137-147. 2010.

http://www.sciencedirect.com/science?_ob=PublicationURL\&_tockey=\%23TOC\%236776\%232010\%23999139998\%231577827\%23FLA\%23\&_cdi=

Clarke, K.R. and Ainsworth, M., 1993. A method of linking multivariate community structure

to environmental variables. Marine Ecology Progress Series 92, 205-219.

Coates, S., Waugh, A., Anwar, A. and Robson, M., 2007. Efficacy of a multi-metric fish index as an analysis tool for the transitional fish component of the Water Framework Directive. Marine Pollution Bulletin 55, 225-240.

Connor, E.F. and McCoy, E.D., 1979. The statistics and biology of the species-area relationship. American Naturalist 113, 791-833.

Costanza, R., D'Arge, R., De Groot, R., Farber, S., Grasso, M., Hannon, B., Limburg, K., Naeem, S., O'Neill, R.V., Paruelo, J., Raskin, R.G., Sutton, P. and Van Den Belt, M., 1997. The value of the world's ecosystem services and natural capital. Nature 387, 253-260.

Courrat, A., Lobry, J., Nicolas, D., Laffargue, P., Amara, R., Lepage, M., Girardin, M. and Le Pape, O., 2009. Anthropogenic disturbance on nursery function of estuarine areas for marine species. Estuarine, Coastal and Shelf Science 81, 179-190.

Dalrymple, R.W., Zaitlin, B.A. and Boyd, R., 1992. Estuarine facies models: conceptual basis and stratigraphic implications. Journal of Sedimentary Petrology 62, 1130-1146.

Daufresne, M., Roger, M.C., Capra, H. and Lamouroux, N., 2003. Long-term changes within the invertebrate and fish communities of the Upper Rhône River: Effects of climatic factors. Global Change Biology 10, 124-140.

Désaunay, Y., Guérault, D., Le Pape, O. and Poulard, J.C., 2006. Changes in occurrence and abundance of northern/southern flatfishes over a 20-year period in a coastal nursery area (Bay of Vilaine) and on the eastern continental shelf of the Bay of Biscay. Scienta Marina 70, 193-200.

Edgar, G.J., Barrett, N.S., Graddon, D.J. and Last, P.R., 2000. The conservation significance of estuaries: a classification of Tasmanian estuaries using ecological, physical and demographic attributes as a case study. Biological Conservation 92, 383-397.

Edgar, G.J., Barrett, N.S. and Last, P.R., 1999. The distribution of macroinvertebrates and fishes in Tasmanian estuaries. Journal of Biogeography 26, 1169-1189.

Elliott, M. and Dewailly, F., 1995. The structure and components of European estuarine fish assemblages. Netherlands Journal of Aquatic Ecology 29, 397-417.

Elliott, M. and Hemingway, K. (Editors), 2002. Fishes in Estuaries. Blackwell Science, Oxford.

Elliott, M. and McLusky, D.S., 2002. The Need for Definitions in Understanding Estuaries. Estuarine, Coastal and Shelf Science 55, 815-827. 
Nicolas, D. etal. Fish under influence: a macroecological analysis of relations between fish species richness and environmental gradients among Eu Estuarine, Coastal and Shelf Science, n86. p. 137-147. 2010.

http://www.sciencedirect.com/science?_ob=PublicationURL\&_tockey=\%23TOC\%236776\%232010\%23999139998\%231577827\%23FLA\%23\&_cdi=

Elliott, M. and Quintino, V., 2007. The Estuarine Quality Paradox, Environmental

Homeostasis and the difficulty of detecting anthropogenic stress in naturally stressed areas. Marine Pollution Bulletin 54, 640-645.

Engle, V.D., Kurtz, J.C., Smith, L.M., Chancy, C. and Bourgeois, P., 2007. A classification of U.S. Estuaries Based on Physical and Hydrologic Attributes. Environmental Monitoring and Assessment 129, 397-412.

European Council Directive, 2000. Directive 2000/60/EC of the European Parliament and of the Council of 23 October 2000 establishing a framework for Community action in the field of water policy. Official Journal of the European Communities 43, 75.

Fiuza, A.F.G., Hamann, M., Ambar, I., del Rio, G.D., Gonzalez, N. and Cabanas, J.M., 1998. Water masses and their circulation off western Iberia during May 1993. Deep-Sea Research Part I-Oceanographic Research Papers 45, 1127-1160.

Franco, A., Elliott, M., Franzoi, P. and Torricelli, P., 2008. Life strategies of fishes in European estuaries: the functional guild approach. Marine Ecology Progress Series $354,219-228$.

Gibson, R.N., 1994. Impact of Habitat Quality and Quantity on the Recruitment of Juvenile Flatfishes. Netherlands Journal of Sea Research 32, 191-206.

Gibson, R.N., Robb, L., Wennhage, H. and Burrows, M.T., 2002. Ontogenetic changes in depth distribution of juvenile flatfishes in relation to predation risk and temperature on a shallow-water nursery ground. Marine Ecology-Progress Series 229, 233-244.

Harris, P.T. and Heap, A.D., 2003. Environmental management of clastic coastal depositional environments: inferences from an Australian geomorphic database. Ocean \& Coastal Management 46, 457-478.

Harrison, T.D. and Whitfield, A.K., 2006. Estuarine typology and the structuring of fish communities in South Africa. Environmental Biology of Fishes 75, 269-293.

Hermant, M., Lobry, J., Poulard, J.C., Désaunay, Y., Bonhommeau, S. and Le Pape, O., in press. Impact of warming on abundance and occurrence of flatfish populations in the Bay of Biscay (France). Journal of Sea Research.

Hyndes, G.A., Potter, I.C. and Lenanton, R.C.J., 1996. Habitat partitioning by whiting species (Sillaginidae) in coastal waters. Environmental Biology of Fishes 45, 21-40.

Keddy, P.A., 1992. Assembly and response rules: two goals for predictive community ecology. Journal of Vegetation Science 3, 157-164. 
Nicolas, D. etal. Fish under influence: a macroecological analysis of relations between fish species richness and environmental gradients among Eu Estuarine, Coastal and Shelf Science, $n^{\circ} 86$. p. 137-147. 2010.

http://www.sciencedirect.com/science?_ob=PublicationURL\&_tockey=\%23TOC\%236776\%232010\%23999139998\%231577827\%23FLA\%23\&_cdi=

Kendall, V.J. and Haedrich, R.L., 2006. Species richness in Atlantic deep-sea fishes assessed

in terms of the mid-domain effect and Rapoport's rule. Deep Sea Research Part I: Oceanographic Research Papers 53, 506-515.

Krebs, C.J., 1999. Ecological Methodology. Addison Wesley, California, USA, 654 pp.

LeBart, L., Morineau, A. and Warwick, K., 1984. Multivariate Descriptive Statistical Analysis. Correspondence Analysis and Related Techniques for Large Matrices. Wiley, New York.

Ley, J.A., 2005. Linking fish assemblages and attributes of mangrove estuaries in tropical Australia: criteria for regional marine reserves. Marine Ecology Progress Series 305, 41-57.

Lowry, M. and Suthers, L., 2004. Population structure of aggregations, and response to spear fishing, of a large temperate reef fish Cheilodactylus fuscus. Marine Ecology Progress Series 273, 199-210.

Maes, J., Van Damme, S., Meire, P. and Ollevier, F., 2004. Statistical modeling of seasonal and environmental influences on the population dynamics of an estuarine fish community. Marine Biology 145, 1033-1042.

Mann, K.H. and Lazier, J.R.N., 1991. Dynamics of marine ecosystems. Biological-physical interactions in the oceans. Blackwell Scientific Publications, Oxford.

McLusky, D.J., 1989. The Estuarine Ecosystem. Blackie, Glasgow-London, 215 pp.

Monaco, M.E., Lowery, T.A. and Emmett, R.L., 1992. Assemblages of U.S. west coast estuaries based on the distribution of fishes. Journal of Biogeography 19, 251-267.

Oberdorff, T., Guégan, J.-F. and Hugueny, B., 1995. Global scale patterns of species richness in rivers. Ecography 18, 345-352.

Olson, D.M., Dinerstein, E., Wikramanayake, E.D., Burgess, N.D., Powell, G.V.N., Underwood, E., C., D'amico, J.A., Itoua, I., Strand, H.E., Morrison, J.C., Loucks, C.J., Allnutt, T.F., Ricketts, T.H., Kura, Y., Lamoreux, J.F., Wettengel, W.W., Hedao, P. and Kassem, K.R., 2001. Terrestrial ecoregions of the world: a new map of life on earth. Bioscience 51, 933-938.

Pauly, D. and Christensen, V., 1995. Primary Production Required to Sustain Global Fisheries. Nature 374, 255-257.

Pease, B.C., 1999. A spatially oriented analysis of estuaries and their associated commercial fisheries in New South Wales, Australia. Fisheries Research 42, 67-86.

Perry, A.L., Low, P.J., Ellis, J.R. and Reynolds, J.D., 2005. Climate change and distribution shifts in marine fishes. Science 308, 1912-1915. 
Nicolas, D. etal. Fish under influence: a macroecological analysis of relations between fish species richness and environmental gradients among Eu Estuarine, Coastal and Shelf Science, n86. p. 137-147. 2010.

http://www.sciencedirect.com/science?_ob=PublicationURL\&_tockey=\%23TOC\%236776\%232010\%23999139998\%231577827\%23FLA\%23\&_cdi=

Peterson, M.S., 2003. A conceptual view of environment-habitat-production linkages in tidal river estuaries. Reviews in Fisheries Science 11, 291-313.

Poff, N.L., 1997. Landscape filters and species traits: towards mechanistic understanding and prediction in stream ecology. Journal of the North American Benthological Society $16,391-409$.

Poff, N.L., Tokar, S. and Johnson, P., 1996. Stream hydrological and ecological responses to climate change assessed with an artificial neural network. Limnology and Oceanography 41, 857-863.

Poore, G.C.B. and Wilson, G.D.F., 1993. Marine species richness. Nature 361, 597-598.

Potter, I.C., Beckley, L.E., Whitfield, A.K. and Lenanton, R.C.J., 1990. Comparisons between the roles played by estuaries in the life cycles of fishes in temperate Western Australia and Southern Africa. Environmental Biology of Fishes 28, 143-178.

Power, M., Attrill, M.J. and Thomas, R.M., 2000. Environmental factors and interactions affecting the temporal abundance of juvenile flatfish in the Thames Estuary. Journal of Sea Research 43, 135-149.

R Development Core Team, 2005. R: a language and environment for statistical 609 computing. R Foundation for Statistical Computing, Vienna, Austria.

Roy, P.S., Williams, R.J., Jones, A.R., Yassini, I., Gibbs, P.J., Coates, B., West, R.J., Scanes, P.R., Hudson, J.P. and Nichol, S., 2001. Structure and function of south-east Australian estuaries. Estuarine, Coastal and Shelf Science 53, 351-384.

Saintilan, N., 2004. Relationships between estuarine geomorphology, wetland extent and fish landings in New South Wales estuaries. Estuarine, Coastal and Shelf Science 61, $591-601$.

Sakamoto, Y., Ishiguro, M. and Kitagawa, G., 1986. Akaike Information Criterion Statistics. D. Reidel Publishing Company, 290 pp.

Santos, A.M.P., Kazmin, A.S. and Peliz, A., 2005. Decadal changes in the Canary Upwelling System as revealed by satellite observations: Their impact on productivity. Journal of Marine Research 63, 359-379.

Smith, K.F. and Brown, J.H., 2002. Patterns of diversity, depth range and body size among pelagic fishes along a gradient of depth. Global Ecology \& Biogeography 11, $313-$ 322.

Spalding, M.D., Fox, H.E., Allen, G.R., Davidson, N., Ferdaña, Z.A., Finlayson, M., Halpern, B.S., Jorge, M.A., Lombana, A., Lourie, S.A., Martin, K.D., McManus, E., Molnar, 
Nicolas, D. etal. Fish under influence: a macroecological analysis of relations between fish species richness and environmental gradients among Eu Estuarine, Coastal and Shelf Science, $n^{\circ} 86$. p. 137-147. 2010.

http://www.sciencedirect.com/science?_ob=PublicationURL\&_tockey=\%23TOC\%236776\%232010\%23999139998\%231577827\%23FLA\%23\&_cdi= J., Recchia, C.A. and Robertson, J., 2007. Marine ecoregions of the world: a bioregionalization of coastal and shelf areas. Bioscience 57, 573-583.

Steele, M.A., Schroeter, S.C. and Page, H.M., 2006. Experimental evaluation of biases associated with sampling estuarine fishes with seines. Estuaries and Coasts 29, 1172-1184.

Thiel, R., Cabral, H. and Costa, M.J., 2003. Composition, temporal changes and ecological guild classification of the ichthyofaunas of large European estuaries - A comparison between the Tagus (Portugal) and the Elbe (Germany). Journal of Applied Ichthyology 19, 330-342.

Thiel, R., Sepulveda, A., Kafemann, R. and Nellen, W., 1995. Environmental factors as forces structuring the fish community of the Elbe Estuary. Journal of Fish Biology 46, 4769.

van der Veer, H.W., Dapper, R. and Witte, J.I.J., 2001. The nursery function of the intertidal areas in the western Wadden Sea for 0-group sole Solea solea (L.). Journal of Sea Research 45, 271-279.

Vogt, J.V., Soille, P., de Jager, A., Rimaviciute, E., Mehl, W., Foisneau, S., Bodis, K., Dusart, J., Paracchini, M.L., Haastrup, P. and Bamps, C., 2007. A pan-European River and Catchment Database. EC-JRC (Report EUR 22920 EN), Luxembourg.

Willig, M.R., Kaufman, D.M. and Stevens, R.D., 2003. Latitudinal gradients of biodiversity: patterns, process, scale and synthesis. Annual Review of Ecology and Systematics 34, 273-309.

Wolanski, E., 2007. Estuarine ecohydrology. Elsevier, Amsterdam, 157 pp. 
Nicolas, D. etal. Fish under influence: a macroecological analysis of relations between fish species richness and environmental gradients among Eut Estuarine, Coastal and Shelf Science, $n^{\circ} 86$. p. 137-147. 2010.

http://www.sciencedirect.com/science?_ob=PublicationURL\&_tockey=\%23TOC\%236776\%232010\%23999139998\%231577827\%23FLA\%23\&_cdi= Figure and table legends

Fig.1: Map of the 135 European estuaries covered in the study and their catchment areas. The $150 \mathrm{~m}$ deep limit of the continental shelf is represented (continuous fine black line off the coast). Symbols correspond to the seven estuary clusters obtained by Ward clustering method on the two main components of PCA (Fig. 2).

Fig. 2: Linearization of species-accumulation curve. Example from results of the Vilaine estuary (France).

Fig. 3: (a) Plot of 135 studied estuaries projected on the two main components of PCA $(62.5 \%$ of total inertia). The seven clusters were obtained by Ward clustering method. Capital letters represent their inertia centroid. For better readability, clusters per estuary are mentioned in Appendix A1. (b) Correlation circle of active abiotic variables with screenplot in the top right corner. The length of the vectors associated to each variable corresponded to their absolute contributions to the determination of the two main PCA components. RD: mean annual river discharge; WA: catchment area; EA: estuary area; EW: entrance width; ED: entrance depth; TR: tidal range; CSW: continental shelf width; SE: source elevation.

Fig. 4: Boxplots per estuary cluster of abiotic variables. The central mark represents the median of the distribution; the edges of the box are the $25^{\text {th }}$ and $75^{\text {th }}$ percentiles. 
Nicolas, D. etal. Fish under influence: a macroecological analysis of relations between fish species richness and environmental gradients among Eut Estuarine, Coastal and Shelf Science, $n^{\circ} 86$. p. 137-147. 2010.

http://www.sciencedirect.com/science?_ob=PublicationURL\&_tockey=\%23TOC\%236776\%232010\%23999139998\%231577827\%23FLA\%23\&_cdi=

Table 1: Quantitative and semi-quantitative environmental attributes used in the estuarine

typology and statistical analyses. Collected data per estuary are shown in appendix A1.

Table 2: Correlation matrix between quantitative environmental attributes. The variables related to system size: catchment area, mean annual river discharge, estuary area and mouth width, are log-transformed. Stars indicate significant values at a 5\% level.

Table 3: Analysis of deviances for the generalized linear models computed on two gear types (beach seines and beam trawls) data set (a) and only on beam trawls data set (b). Selected variables were introduced into models in the following order: 1) Sampling effort factor, 2) abiotic attributes. The italicized lines correspond to variables that were introduced in the model instead of the just above variable. Df: residual degree of freedom; Resid. Dev: Residual deviance in percentage; Sig.: significance, *: when p-value $<5 \%, * *:<1 \%, * * *$ : $<0.1 \%$; Slope: slope sign.

\section{Appendix A}

Table A1: The 135 European tidal estuaries covered in the study with their respective environmental attributes. Main sources, units and classes for qualitative descriptors are mentioned in Table 1. The order of estuaries (Id) refers to figure 1. The "Estuary cluster" column refers to clusters obtained by Ward clustering method on the two main components of the principal component analysis taking into account solely quantitative abiotic descriptors (see Materials \& Methods and Fig.3). 
Nicolas, D. etal. Fish under influence: a macroecological analysis of relations between fish species richness and environmental gradients among Eut Estuarine, Coastal and Shelf Science, $n^{\circ} 86$. p. 137-147. 2010.

http://www.sciencedirect.com/science?_ob=PublicationURL\&_tockey=\%23TOC\%236776\%232010\%23999139998\%231577827\%23FLA\%23\&_cdi=

Table A2: Characteristics of beam trawls and beach seines used by different European

partners.

\section{Appendix B}

Table B1: Matrix of species censused per sampled estuary during the selected WFD fishing surveys (2004-2007). Data sources are indicated in the acknowledgements. The order of estuaries (Id) refers to figure 1. The last columns indicate which year(s) and which season(s) autumn and/or spring - an estuary was sampled with which gear type(s) - beach seine and/or beam trawl. Pooled values of species richness index $(S R / \ln (S))$ are mentioned last. The column headed "SR/ln(S)_BT" refers to the fish dataset based solely on beam trawl samples. The reference for species names was based on Fishbase (www.fishbase.org). Taxa not identified to the species level (e.g. Atherina_sp or Clupeidae) were assumed to be different species from the others collected in an estuary. Gobiidae were not always identified to the species level, which could bias species richness values. As they occurred in all estuaries and thus are not indicative species, they were eliminated from the analysis. Among the 7,364 fish caught, 132 species were identified from 53 different families. 
Nicolas, D. etal. Fish under influence: a macroecological analysis of relations between fish species richness and environmental gradients among Eu Estuarine, Coastal and Shelf Science, $n^{\circ} 86$. p. 137-147. 2010.

http://www.sciencedirect.com/science?_ob=PublicationURL\&_tockey=\%23TOC\%236776\%232010\%23999139998\%231577827\%23FLA\%23\&_cdi= Fig.1:

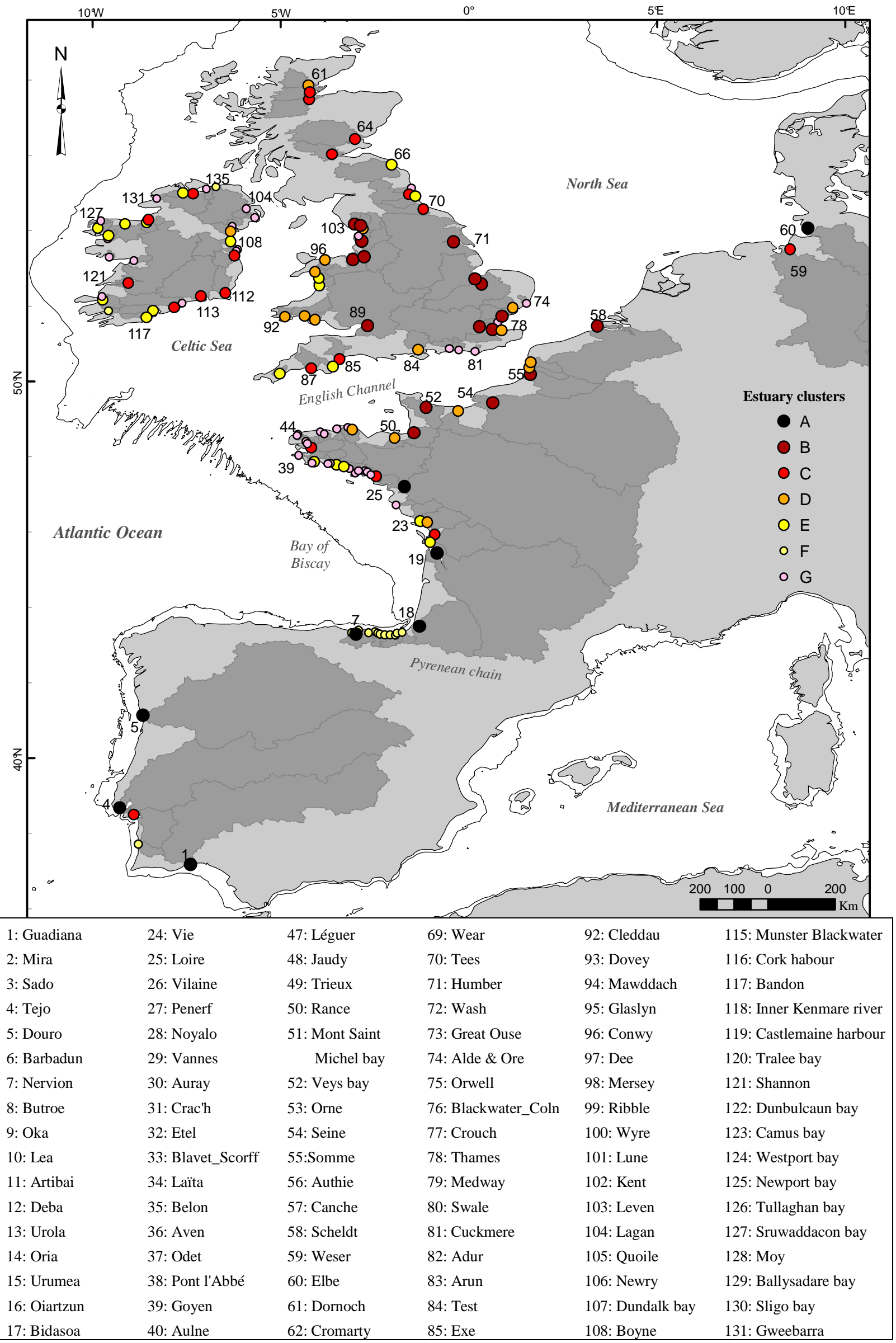


Nicolas, D. etal. Fish under influence: a macroecological analysis of relations between fish species richness and environmental gradients among Eu Estuarine, Coastal and Shelf Science, $n^{\circ} 86$. p. 137-147. 2010.

\begin{tabular}{|c|c|c|c|c|c|}
\hline 18: Adour & 41:Daoulas & 63: Moray_Beauly & 86: Dart & 109: Rogerstown & 132: Swilly \\
\hline 19: Gironde & 42: Elorn & 64: Tay & 87: Tamar & 110: Broadmeadow & 133: Faughan \\
\hline 20: Seudre & 43: Aber Benoît & 65: Forth & 88: Fal & 111: Liffey & 134: Roe \\
\hline 21: Charente & 44: Aber Wrac'h & 66: Tweed & 89: Severn & 112: Slaney & 135: Bann \\
\hline 22: Sèvre Niortaise & 45: Penzé & 67: Blyth & 90: Loughor & 113: Suir & \\
\hline 23: Lay & 46: Morlaix & 68: Tyne & 91: Tywi & 114: Colligan & \\
\hline
\end{tabular}


Nicolas, D. etal. Fish under influence: a macroecological analysis of relations between fish species richness and environmental gradients among Eut Estuarine, Coastal and Shelf Science, $n^{\circ} 86$. p. 137-147. 2010.

Fig. 2:

a)

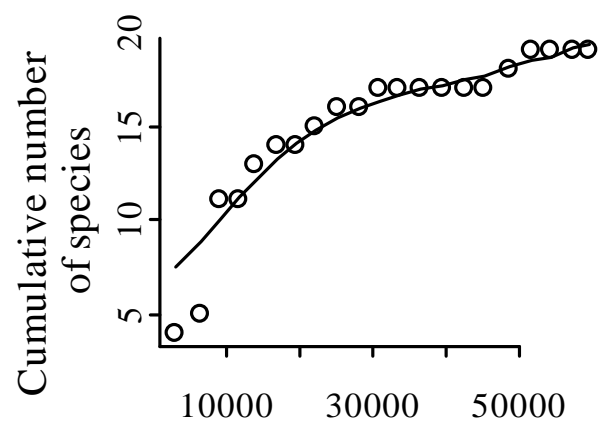

Sampled surface $\left(\mathrm{m}^{2}\right)$ b)

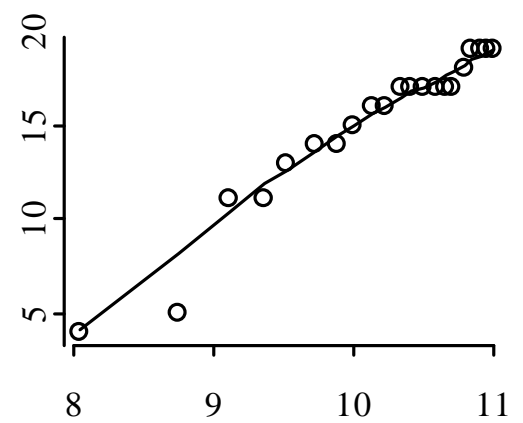

Log-tranformed sampled surface 
Nicolas, D. etal. Fish under influence: a macroecological analysis of relations between fish species richness and environmental gradients among Eut Estuarine, Coastal and Shelf Science, $n^{\circ} 86$. p. 137-147. 2010.

http://www.sciencedirect.com/science?_ob=PublicationURL\&_tockey=\%23TOC\%236776\%232010\%23999139998\%231577827\%23FLA\%23\&_cdi= Fig. 3:

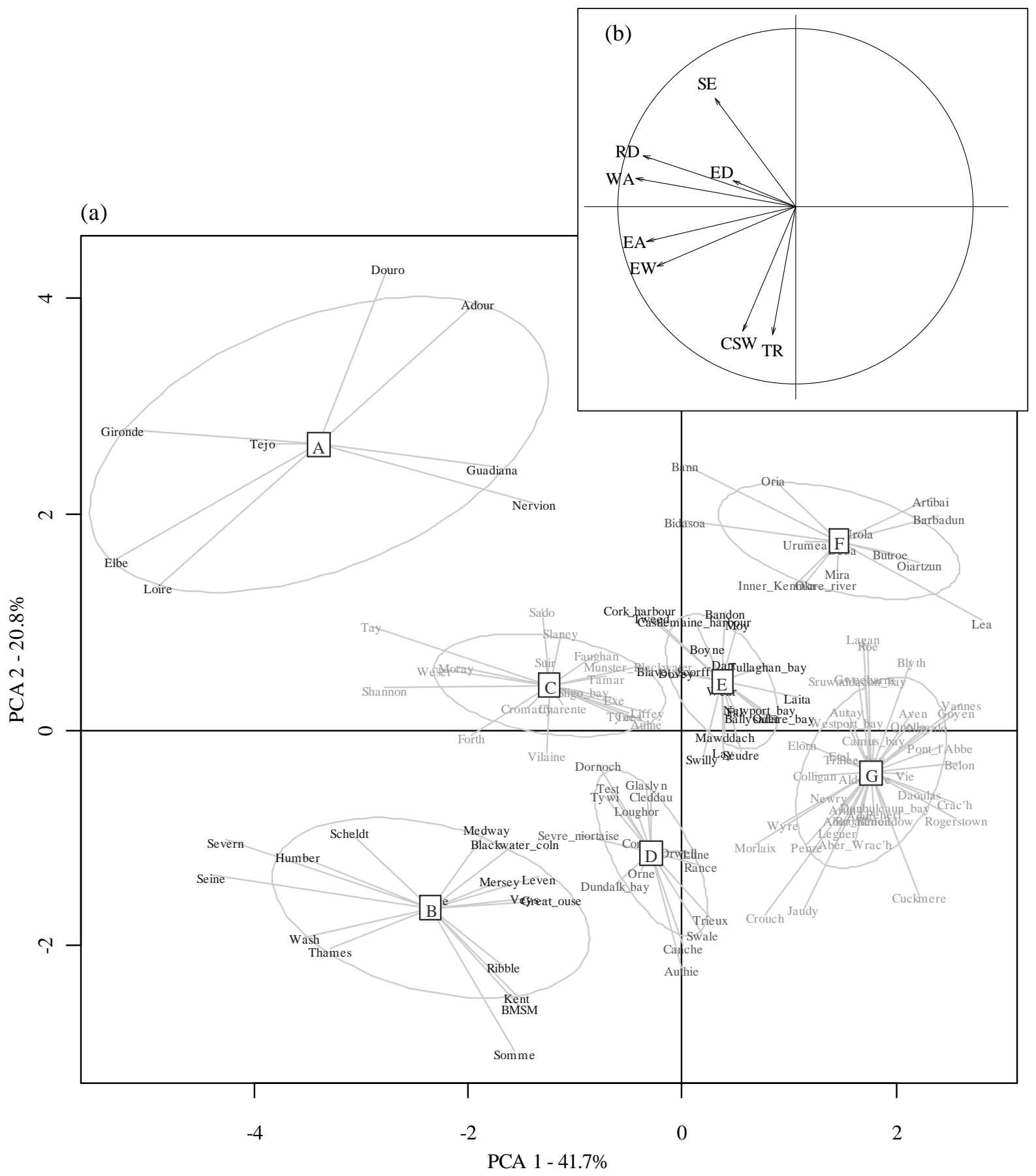


Nicolas, D. etal. Fish under influence: a macroecological analysis of relations between fish species richness and environmental gradients among Eu Estuarine, Coastal and Shelf Science, $n^{\circ} 86$. p. 137-147. 2010.

http://www.sciencedirect.com/science?_ob=PublicationURL\&_tockey=\%23TOC\%236776\%232010\%23999139998\%231577827\%23FLA\%23\&_cdi=

Ln(Catchment area)

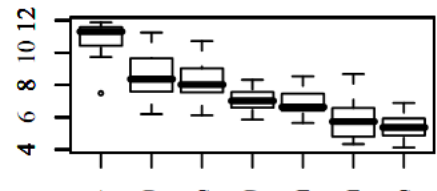

$\begin{array}{lllllll}\text { A } & \text { B } & \text { C } & \text { D } & \text { E } & \text { F } & \text { G }\end{array}$

Ln(Estuary area)

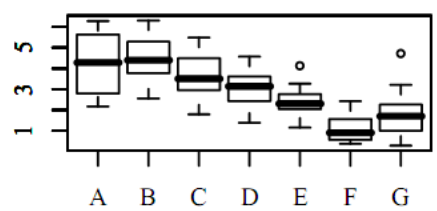

Ln(Mouth width)

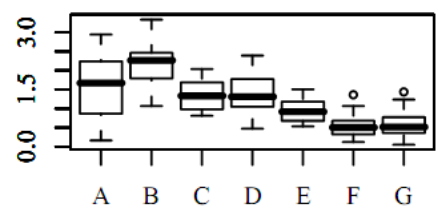

Tidal range (m)

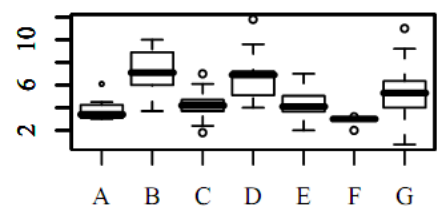

Continental shelf width (km)

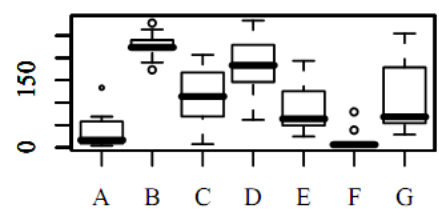

Source elevation (m)

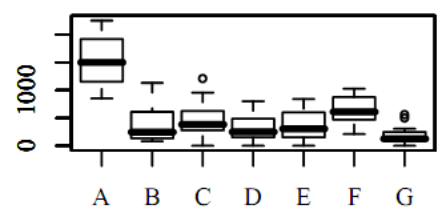

Intertidal area types

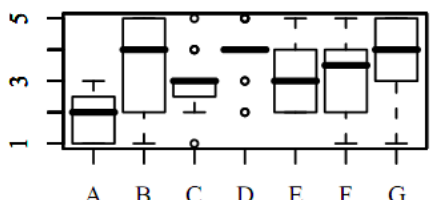

Wave exposure

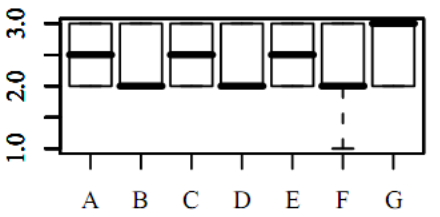

Latitude (decimal degrees)

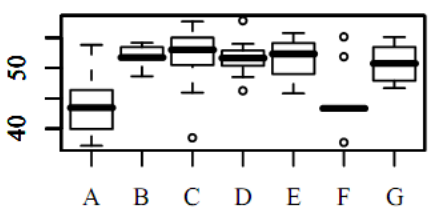


Nicolas, D. etal. Fish under influence: a macroecological analysis of relations between fish species richness and environmental gradients among Eu Estuarine, Coastal and Shelf Science, $n^{\circ} 86$. p. 137-147. 2010.

http://www.sciencedirect.com/science?_ob=PublicationURL\&_tockey=\%23TOC\%236776\%232010\%23999139998\%231577827\%23FLA\%23\&_cdi=

Table 1

\begin{tabular}{ll}
\hline Attributes & Units or classes \\
\hline Watershed scale & \\
Latitude & Decimal degrees \\
Source elevation & Metres \\
Catchment area & Square kilometres \\
Mean annual river discharge & Metres cube per second
\end{tabular}

Source

\section{Estuary scale}

Estuary area

Entrance width

Entrance depth

Intertidal area type

Tidal range

Wave exposure

Coastal scale

Continental shelf width (minimal distance to the limit of 150m deep, Fig.1)

Littoral substrate
Square kilometres

Kilometres

Metres

Percentage of total estuary area: $1: 0-20 \%$; 2:20-40\%; 3:40-60\%; 4:60-80\%; 5:80-100\%

Metres

1:Extremely exposed ;

2:Moderately exposed ;

3:Sheltered

Kilometres

1:Mud; 2:Mud/Sand 4:Sand/gravel; 5:Rock
Google Earth

Literature

Literature; ArcGis software

Literature; river website; water agencies' databases (ROI Environmental Protection Agency (EPA): http://www.epa.ie/, UK Estuaries Database 2003: http://www.bodc.ac.uk/, French hydrology database: http://www.hydro.eaufrance.fr/, French water agencies: http://www.lesagencesdeleau.fr/)

Literature; ArcGis software

Google Earth

Marine charts

Literature; ArcGis software; Marine charts available on Navicarte seaPro software

Literature

Literature; expert communications

ArcGis software

3:Sand; Marine sediment maps (Borja et al., 2000; Quéro and Vayne, 2005) 
Nicolas, D. etal. Fish under influence: a macroecological analysis of relations between fish species richness and environmental gradients among European tidal estuaries. Estuarine, Coastal and Shelf Science, $n^{\circ} 86$. p. 137-147. 2010.

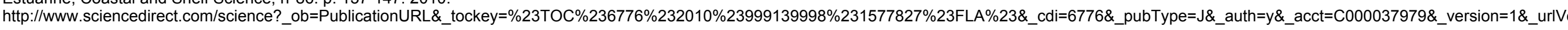

Table 2

\begin{tabular}{|c|c|c|c|c|c|c|c|c|c|}
\hline & $\begin{array}{l}\text { Catchment } \\
\text { area }\end{array}$ & $\begin{array}{c}\text { Mean river } \\
\text { annual } \\
\text { discharge }\end{array}$ & $\begin{array}{c}\text { Estuary } \\
\text { area }\end{array}$ & $\begin{array}{l}\text { Mouth } \\
\text { width }\end{array}$ & Mouth depth & Tidal range & $\begin{array}{l}\text { Continental } \\
\text { shelf width }\end{array}$ & $\begin{array}{c}\text { Source } \\
\text { elevation }\end{array}$ & Latitude \\
\hline Catchment area & 1 & & & & & & & & \\
\hline $\begin{array}{r}\text { Mean river annual } \\
\text { discharge }\end{array}$ & $0.894 *$ & 1 & & & & & & & \\
\hline Estuary area & $0.647 *$ & $0.554 *$ & 1 & & & & & & \\
\hline Mouth width & $0.564 *$ & $0.494 *$ & $0.764 *$ & 1 & & & & & \\
\hline Mouth depth & 0.217 & $0.226^{*}$ & $0.369 *$ & 0.153 & 1 & & & & \\
\hline Tidal range & 0.019 & -0.034 & 0.171 & 0.228 & -0.061 & 1 & & & \\
\hline Continental shelf width & 0.192 & 0.098 & 0.244 & $0.360^{*}$ & -0.051 & $0.347 *$ & 1 & & \\
\hline Source elevation & $0.454 *$ & $0.540^{*}$ & 0.163 & 0.134 & 0.068 & -0.180 & -0.165 & 1 & \\
\hline Latitude & -0.026 & 0.025 & 0.172 & 0.180 & 0.075 & 0.063 & $0.571 *$ & -0.263 & 1 \\
\hline
\end{tabular}


Nicolas, D. etal. Fish under influence: a macroecological analysis of relations between fish species richness and environmental gradients among Eu Estuarine, Coastal and Shelf Science, $n^{\circ} 86$. p. 137-147. 2010.

http://www.sciencedirect.com/science?_ob=PublicationURL\&_tockey=\%23TOC\%236776\%232010\%23999139998\%231577827\%23FLA\%23\&_cdi=

Table 3:

Introduced variables

Df Resid. Dev.

Sig.

Slope

(a) TWO GEAR TYPES MODELS

$S R / L n(S) \sim$ number of gear types + size effect + continental shelf width (or source elevation)

Null

+ Number of gear types

+ Size effect (- PCA Component 1)

+ Continental shelf width or + Source elevation
80

79

78

77

77
100

88.2

78.9

74.4

71.7

(b) BEAM TRAWL MODELS

$S R / I n(S) \sim$ size effect + continental shelf width (or source elevation) + mouth depth

Null

+ Size effect (- PCA Component 1)

+ Continental shelf width or + Source elevation

+ Mouth depth
44
100

$80.1 \quad * * * \quad+$

$63.6 * * *+$

69.4

57.3 